\title{
Financialisation Issues in a Post-Keynesian Stock-flow Consistent Model
}

\begin{abstract}
Marc Lavoie*
This paper presents a stock-flow consistent growth model which is set in the Post-Keynesian tradition. A key feature of the model, however, is that real government expenditures grow at a rate which is compatible over the long period with a constant rate of unemployment (at the "natural rate of growth"). The model incorporates a detailed description of the household, production, banking and government sectors. This paper focuses on changes in parameters that are tied with financialization. The effects on the following changes are examined: the target proportion of retained earnings to investment, the proportion of profits distributed as dividends, the propensity of households to hold equities, and the propensity of households to take new loans as a proportion of their personal income. There is also a short analysis of the impact of a change in the loan repayment ratio and in the loan default ratio.

JEL classifications: $E_{I 2}, O_{42}$
\end{abstract}

Keywords: financialization, growth, buffer stocks, disequilibria

* Department of Economics, University of Ottawa. I wish to thank the participants in the Berlin October 2007 conference session for their comments, as well as the two referees of the journal, who provided useful remarks.

Correspondence Address:

Marc Lavoie, Department of Economics University of Ottawa, 55 Laurier E., Ottawa (Ontario), Canada KIN 6N5, email: marc.lavoie@uottawa.ca

Received 2I January 2008, accepted 05 April 2008

(C) INTERVENTION 5 (2), 2008, 33I-356 


\section{Introduction}

Recently there has been a great deal of interest among Post-Keynesian economists about the topic of financialization and its impact on major macroeconomic variables. Financialization is a catch-all term, that refers to a multiplicity of phenomena that have especially occurred over the last 20 years or so, as they have been identified by a variety of authors (among many others, Duménil/Lévy 200I, Stockhammer 2004, Epstein 2005). Financialization, broadly speaking, refers to the enlarged influence of financial actors and financial motives on our day-to-day life. At the international level, this can certainly be associated with the liberalization of the capital account; at the domestic level, financialization is tied to the transition from a heavily regulated financial industry to a liberalized one, where the traditional distinction between the various financial institutions have become ever blurred. This has been accompanied by the growing engagement of non-financial corporations in financial markets, as well as the growing importance of non-bank financial intermediaries, such as hedge funds, and securitization, with the consequences that can be most obviously observed in the United States since early 2008.

Financialization is also associated with the rising share of profits in national income, along with the rising importance of rentiers and the stock market, due to the ascendancy of a shareholder value orientation. Financialization is often defined as a change in corporate governance - a new or revamped finance-led accumulation regime - where sales growth is driven by higher dividends and a booming stock market, along with looser credit standards and hence higher household debt ratios. This is essentially how financialization will be dealt with here.

The purpose of the present paper is to present some of the results relevant to financialization that can be obtained with the help of the growth model that constitutes the core of Chapter II of the book recently published by Godley and Lavoie (2007a). The book is rather ambitious, as it attempts to study simultaneously topics or variables which are often treated in isolation, in particular the real and the monetary sides - credit, money, and wealth on the one hand, and income and production on the other hand. There are two means by which this integration task is accomplished: stock-flow consistency and simulations.

By stock-flow consistency, we mean essentially four things (see also Dos Santos 2006). First, as mainstream authors usually insist, agents or sectors face budget constraints, and these must be explicitly taken into account. Second, as part of the budget constraints, there are financial constraints, so that an explicit and complex financial sector must accompany the production sector. Third, all sectors of the economy are intertwined with one another, and the links between these sectors must be explicitly recognized. From this arises the saying: everything must come from somewhere and go somewhere, without black holes. Fourth, the evolution of the entire system can be characterized by claiming that the configuration of stock variables (tangible and financial), at the beginning of each period, is a summary description of past history. From there, transactions plus capital gains yield the stock variables of the next period. Thus our models are set in what we claim to be historical time. We believe, as some colleagues have put it to us, that stock-flow consistency with 
simple adjustment reaction functions, often linking stock-flow targets, can play an essential role in heterodox macroeconomics, as it provides a potential for common ground for all heterodox schools, just like the maximizing representative agent seems to be the standard of mainstream economics. Stock-flow consistency as defined here fulfils what Pasinetti (2005: 84I) calls one of the constructive features of the Cambridge School of Keynesian economics - the need for internal consistency, and not only formal rigour.

A model that tries to show some realistic features, with non-linearities for instance, quickly becomes quite complicated. To handle such models, we resort to simulations. This is not as fancy as analytical study, but we have stuck to it nonetheless. Its major drawback is that some of the results could be, and in many cases certainly are, sensitive to the values taken by the assumed parameters, although we make the conjecture that stock-flow consistency reduces the range of possible outcomes. Our hope is that others, perhaps more skilled than we are, will try various combinations of these parameters in the future and will be able to assess how solid our current results are. In addition, it is also our hope that others will adopt the stock-flow consistency method, and build models of their own, with their own assumptions or closures, as Lance Taylor and Amitava Dutt call them. In fact both of these tasks are already happening (Zezza/Dos Santos 2004, Clévenot 2006, van Treeck 2007, Skott/Ryoo 2008, Le Héron/Mouakil 2008). I should add that it will be facilitated in the future, as there now exist EViews versions of the Godley and Lavoie (2007a) models, on the website of the book, built by Gennaro Zezza. ${ }^{\text {I }}$

The Chapter II model of Godley and Lavoie (2007a) is a closed-economy growth model that combines households, firms, banks, a public sector, and the central bank. As many results are led by it, we deal immediately with the crucial issue of the closure of the model. Government expenditures on goods and services grow at a rate which turns out to be the growth rate of labour productivity, which, in the simulations, has been set at $3 \%$. Thus, in the model, the main autonomous demand component grows at a rate which is determined by the supply side - the growth rate of labour productivity - under the assumption of zero population growth. There are many other possible closures, such as the one to be found in Lavoie and Godley (20OI-2), where the rate of accumulation is not constrained by supply factors and is freely determined by aggregate demand. But the chosen closure of the present model is the easiest closure to make if one wishes to take inflation and unemployment rates into account.

In what follows, I identify the main features of the model, and then I present the main results relevant to the financialization issues. This will be done with the help of charts reproducing the evolution of key variables of the model, as they move through time. The effects on the following changes are examined: the target proportion of retained earnings to investment, the proportion of profits distributed as dividends, the propensity of households to hold equities, and the propensity of households to take new loans as a proportion of their personal income. There is also a short analysis of the impact of a change in the loan repayment ratio and in the loan default ratio. 


\section{Main Features of the Model}

As said above, there are five sectors in the model: firms, households, banks, the public sector, and the central bank. Table I below provides the balance sheet of the economy described by the model, and thus provides the assets and liabilities of each sector. The only unconventional feature of the balance sheet matrix is the term $O F$ which describes the own funds of banks - the value of their equity. It is assumed that whereas production firms are corporations valued by the stock market, banks are privately-held companies, which do not issue stocks. As a result, the net worth $\mathrm{OF}_{b}$ of these banks belongs to the private owners of the banks, and must appear as part of the net wealth of households. The main drawback of the model, as presented in the balance sheet of Table I, is that (non-financial) firms do not hold any financial asset. In the real world, besides tangible capital, about half of the assets of firms are made up of financial assets. It would be more realistic to add the financial assets held by corporations but the model is already complicated enough. This, however, stops us from examining the consequences of what some economists, such as Stockhammer (2004), consider to be a crucial element of financialization.

\section{Table I: The Balance Sheet of the Growth Model}

\begin{tabular}{lcccccc}
\hline & Households & Firms & Govt & Central bank & Banks & $\Sigma$ \\
\hline Inventories & & $+I N$ & & & & $+I N$ \\
Fixed capital & & $+K$ & & & & $+K$ \\
Cash & $+H_{h}$ & & & $-H$ & $+H_{b}$ & 0 \\
\hline Deposits & $+M$ & & & & $-M$ & 0 \\
Bills & $+B_{h}$ & & $-B$ & $+B_{c b}$ & $+B_{b}$ & 0 \\
Bonds & $+B L . p_{b L}$ & & $-B L . p_{b L}$ & & & 0 \\
Loans & $-L_{h}$ & $-L_{f}$ & & & $+L$ & 0 \\
Equities & $+e . p_{e}$ & $-e . p_{e}$ & & & & 0 \\
Bank capital & $+O F_{b}$ & & & & $-O F_{b}$ & 0 \\
\hline Net wealth & $-V_{h}$ & $-V_{f}$ & $-V_{g}$ & 0 & 0 & $-(I N+K)$ \\
$\Sigma$ & 0 & 0 & 0 & 0 & 0 & 0 \\
\hline
\end{tabular}

$I N=$ inventories; $K=$ fixed capital; $H=$ cash; $M=$ bank deposits; $B=$ Treasury bills; $B L=$ the number of long-term bonds; $p_{b L}=$ the price of long-term bonds; $L=$ bank loans; $e=$ the number of stock market equities; $p_{e}=$ the price of equities; $O F=$ own funds (own capital); $V=$ net wealth.

As to the behavioural equations of the model, I first start with the main features of the firm sector. ${ }^{2}$ Our firms follow normal-cost pricing procedures, based on an estimate of normal

2 To save space, and also to spare time for less mathematically-oriented readers, the roo or so equations of the model are left aside. Those who wish to get a complete list can either get them from chap- 
historical unit costs. They need not be the actual unit cost, as normal unit costs depend on trend productivity whereas actual unit costs depend on cyclical productivity. There is a discrepancy between normal and actual labour productivity because employment adjusts partially to demand increases. Pricing also adjusts partially. The markup on normal historical unit costs depends on planned entrepreneurial profits, which themselves depend on dividends to be distributed, based on the latest profit record, and on planned retained earnings, which depend on past investment. Firms borrow essentially to finance inventories. Fixed investment which is not financed by retained earnings is normally financed by the issue of equities. The rate of accumulation depends on the rate of capacity utilisation and the real interest rate.

We assume that households take inflation losses on their assets into account. Households are assumed to consume on the basis of their past net wealth and on the basis of their current disposable income, net of interest payments on loans, incremented by their net additions in outstanding loans - in other words we take full account of personal loans. The crucial assumption here is that the gross amount of new loans is a fraction of personal income, and that this fraction depends negatively on the real interest rate. The other behavioural equations involve portfolio decisions, which take the usual Tobinesque form, with all their adding-up constraints. It is assumed, however, that cash is only held as a fraction of consumer expenditures. For simplicity we do not divide households into two classes, and households treat wage, interest and dividend income, but not capital gains, in an identical way.

As already pointed out, real pure government expenditures (excluding debt servicing) grow at a rate which is equal to that of labour productivity (or the natural growth rate). Taxes are collected on personal income only. Cash, bank reserves, bills and bonds are supplied on demand, at the short and long interest rates set by the central bank. In other words, both the short and the long interest rates are under the control of the central bank and the public sector (for instance, the government issues less long-term bonds relative to Treasury bills if the demand for long-term assets, relative to short-term assets, falls). The monetization of the public debt is entirely demand-determined, and is not under the control of the central bank, nor under that of the government. There is no reaction function of the central bank, however. The central bank sets nominal interest rates.

The banking sector in this model contains many non-linearities. Banks supply loans and deposits on demand (credit rationing is implicitly found in the demand functions of firms and households, for instance, by claiming that less loans will be demanded, or granted, when real interest rates are higher). An important behavioural equation for banks is based on the bank liquidity ratio relative to its target range. The amount of bills held by banks divided by the amount of deposits is the bank liquidity ratio. When this ratio is below the target range, banks raise the deposit interest rate to attract deposits, and vice-versa when it is above the range. As to the lending rate relative to the deposit rate, it depends on how high is the actual capital adequacy ratio relative to its target (as defined by the Bank for Interna-

ter II of Godley and Lavoie (2007a), or better still, they can get them from Gennaro Zezza's website, URL: http://gennaro.zezza.it/software/models. 
tional Settlements ([BIS)] rules). When the actual ratio is below target, as when faced with unexpected non-performing loans, banks will tend to raise the lending rate relative to the deposit rate, in order to raise retained profits and hence their own funds. ${ }^{3}$

Finally, we need to explain how inflation is determined in our model. We assume, in line with a wide array of economists, both heterodox and orthodox, a kind of inflation based on conflictual claims (Cripps/Godley 1976, Rowthorn 1977, Layard et al. 1991). We assume that workers and their unions target a real wage rate, which is a function of the productivity level and labour market tightness, here proxied by the rate of employment relative to full employment. Nominal wage increases are proportional to the discrepancy between the target and the actual real wage rate. However, in line with recent empirical evidence, we assume away the impact of aggregate demand as long as the employment rate is within a »normal« range (the Phillips curve is assumed to be flat within that "normal« range, as argued in Kriesler/Lavoie 2007).

A main feature of our models is that markets usually do not clear in the usual sense. For each sector there is a "buffer", a variable which will absorb the shocks imparted to the economy. In the case of firms, the buffer is the stock of inventories, along with the amounts borrowed from banks, although firms attempt to bring the inventories to sales ratio to a target level over the long run. The buffer of households is their money deposits, which are the residual element of the portfolio functions. They also have a long-run target about bank deposits, the target deposit to wealth ratio, which is part of their portfolio decisions. In the case of the government sector, the buffer is the amount of bills which they issue, given the amount of bonds which are being demanded and given the government deficit. Had the government decided to target a given ratio between short-term and long-term securities, the long-term interest rate would become endogenous. ${ }^{4}$ The buffer of the central bank is the amount of bills which they end up holding. As to commercial banks, their buffer is also the amount of bills which they hold, since they provide loans and deposits on demand and are constrained by the legal requirements on reserves, although in the long run they attempt to control the size of their bill holdings relative to their clients' deposits.

Duménil and Lévy (1993: II3) argue that such behaviour is based on »disequilibrium microeconomics«. Agents have long-run targets, from which actual values can deviate. As economic agents observe and measure disequilibria from these long-run targets, they modify their behaviour in a gradual and adaptive way.

3 Indeed, it has been shown by Hubbard et al. (2002) that banks with low realised capital adequacy ratios are prone to set higher lending rates, thus providing direct empirical justification for the equation determining the interest rate on loans that we suggest.

4 This kind of closure is illustrated in Godley and Lavoie (2007a: ch. 5). 


\section{The Impact of Parameter Changes Related to the Behaviour of Firms}

We do two sets of experiments with parameters related to the behaviour of firms. First we increase the proportion of gross investment which firms attempt to finance through retained earnings; second, we increase the proportion of profits distributed as dividends.

\section{I Increasing the Proportion of Gross Investment Financed by Retained Earnings}

We assume in our model that the target mark-up is a positive function of planned retained earnings of firms which are set as a proportion $\Psi_{U}$ of gross investment expenditures undertaken in the previous period. The complement of this proportion, $\left(1-\Psi_{U}\right)$, is to be raised on the capital markets, by issuing new equities. A possible experiment is thus to assume an increase in the target proportion of investment to be financed by internal funds (indeed, we shall assume that there is no issue of equities anymore). Such an increase simultaneously implies a reduction in new equity issues, thus reducing the relative amount of equities on the stock market. ${ }^{5}$ Under such circumstances, we should expect the price of equities to rise. Is this what is being observed?

Let us first deal with the target mark-up. Since the mark-up is now designed to generate more profits, a higher target proportion of gross investment financed by retained earnings generates a higher ideal costing margin.

The increase in the ideal costing margin can indeed be observed with the help of Figure Ia, with the brisk increase in the actual costing margin $\varphi .^{6}$ The increase in prices and price inflation, and hence the reduction in the real wage caused by this higher costing margin immediately generates wage inflation, as shown in Figure $\mathrm{Ib}$, thus yielding a clear illustration of conflict inflation, where inflation is driven by conflicting claims over the distribution of income. In the present case, the real wage target of workers is being frustrated by the increase in the costing margin that has been implemented by firms. Wage demands are however tempered by the slowdown in economic activity, but still, in the long run, wages rise at about $4.25 \%$ whereas they were rising at a $3.2 \%$ rate in the initial steady state.

Figure Ic shows that real consumption and the employment rate (and hence real output) drop like a rock in the short run, only to partially recover in the following periods, reaching new steady state levels which are still lower than those of the baseline solutions. Even though we have not assumed propensities to consume that are differentiated on the basis of income sources or social classes, the reduction in the real wage arising from the higher costing margin does have negative consequences for output and the employment rate. The

5 Indeed parameters could be such that the absolute amount of equities is reduced, as has occurred since the 1980 in the United States (Brennan 2008).

6 Note that the years shown on the horizontal axis are meaningless; they simply arise from the simulation program, MODLER, which we used thanks to its conceptor, Charles Renfro. The experiments are such that the shocks occur in the year denoted "1965". 
cause of this, however, is not the standard income distribution effect found in Kaleckian or Keynesian Cambridge models, where higher profit shares slow down the economy because of the assumed higher propensity to save out of profits. Rather, this effect here is tied to the higher inflation rates associated with greater conflicts over income distribution arising out of the higher required mark-up.

Why are higher inflation rates associated with lower activity relative to the baseline case? The reasons are not self-evident. It turns out, as already argued by Godley and Cripps (1983: 245) that higher inflation rates with constant nominal interest rates generate a real fiscal stance which is more restrictive, thus slowing down the economy relative to the baseline case (despite the favourable impact of lower real interest rates on investment). ${ }^{7}$ If higher inflation rates are accompanied by higher nominal interest rates (and constant real rates), this generates capital losses on bonds, and indirect capital losses on equity, thus inducing a slowdown in real consumption and real activity relative to the baseline case.

Figure Ia: Evolution of the Costing Margin of Firms, Following an Increase in the Target Proportion of Gross Investment Being Financed by Gross Retained Earnings

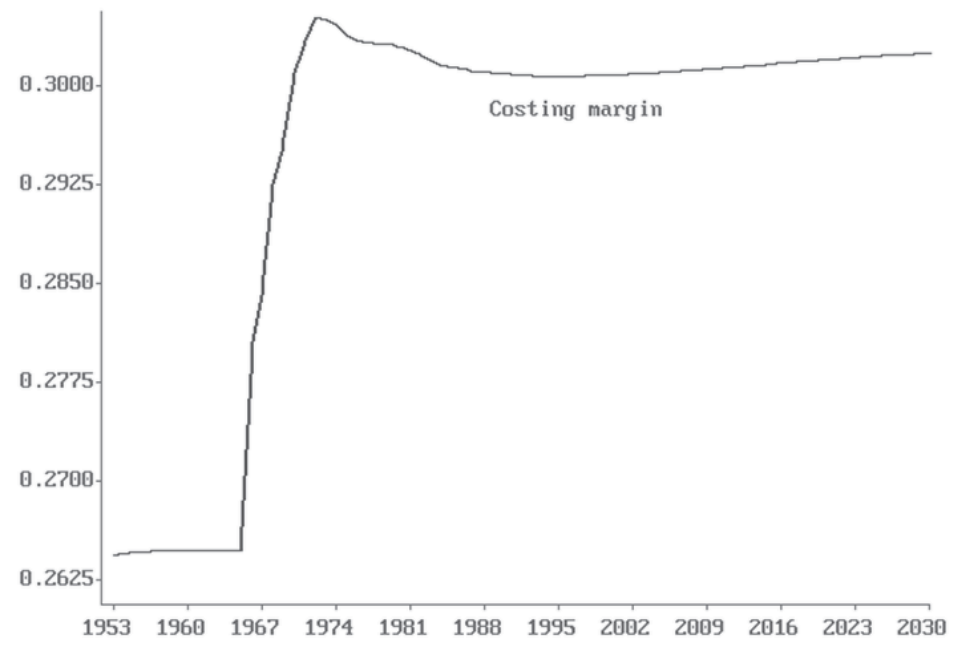

7 Since the real interest rate is lower, while the real rate of accumulation must come back to three percent in the long run, this implies that the rate of capacity utilization must be lower than in the baseline solution. 
Figure Ib: Evolution of the Wage Inflation Rate, Following an Increase in the Target Proportion of Gross Investment Being Financed by Gross Retained Earnings

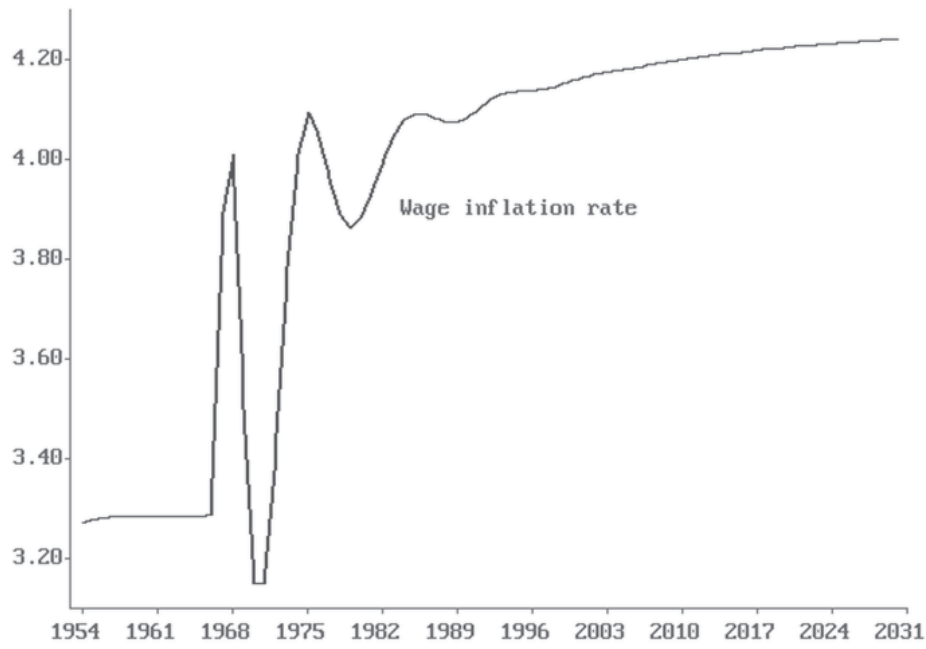

Figure Ic: Evolution of the Employment Rate and of Real Consumption, Relative to the Baseline Solution, Following an Increase in the Target Proportion of Gross Investment Being Financed by Gross Retained Earnings

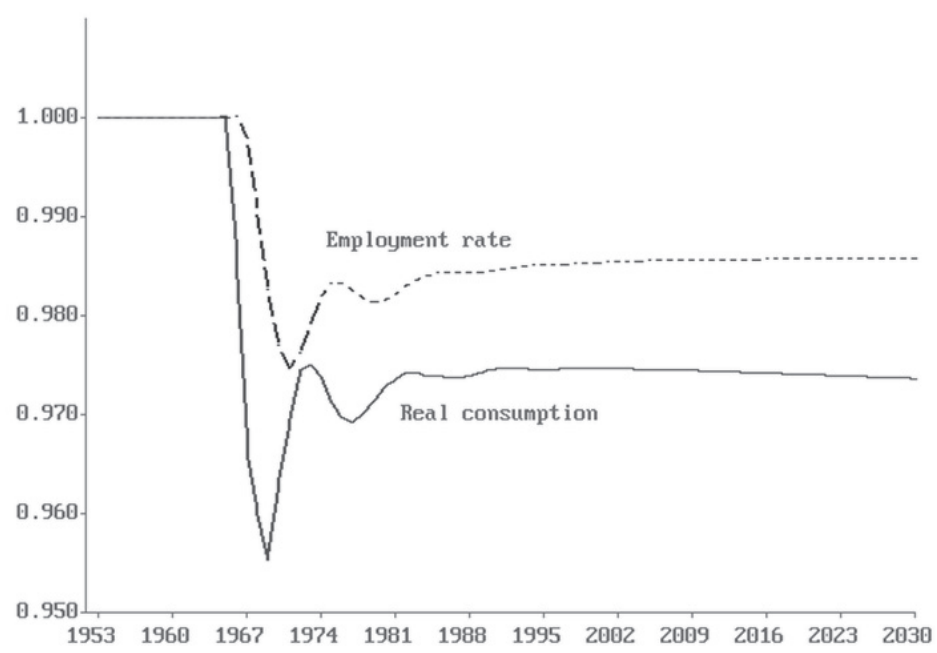

Figure Id: Evolution of Tobin's $q$ Ratio and of the Price Earnings Ratio, Relative to the Baseline Solution, Following an Increase in the Target Proportion of Gross Investment 
Being Financed by Gross Retained Earnings, Which Also Corresponds to a Decrease in the Proportion of Investment Being Financed by New Equity Issues

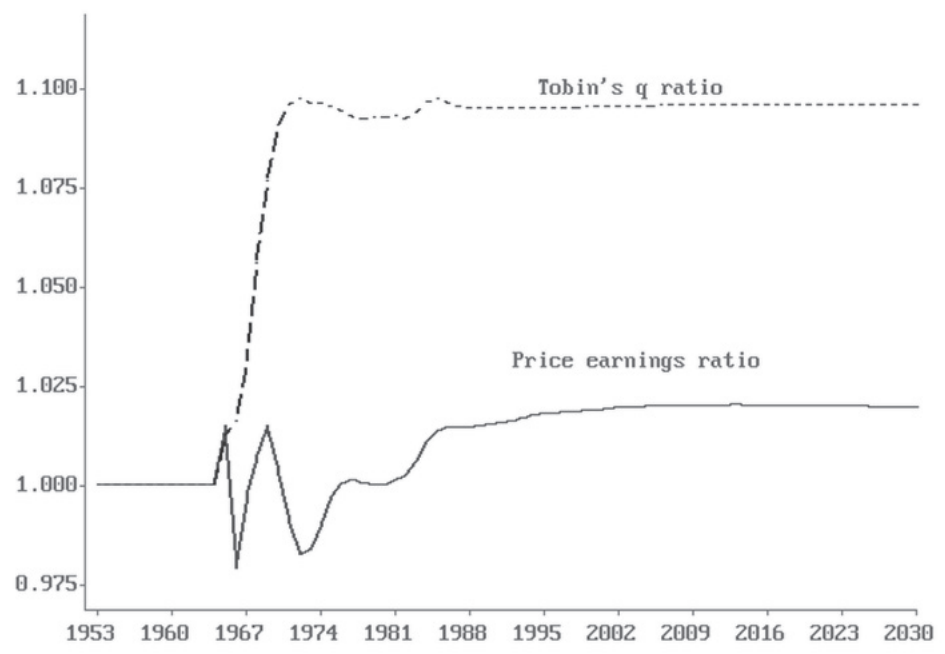

Figure Ie: Evolution of the Deflated Averaged Growth Rate of the Entrepreneurial Profits of Firms and of the Deflated Growth Rate of Equity Prices, Following an Increase in the Target Proportion of Gross Investment Being Financed by Gross Retained Earnings and No New Equity Issues

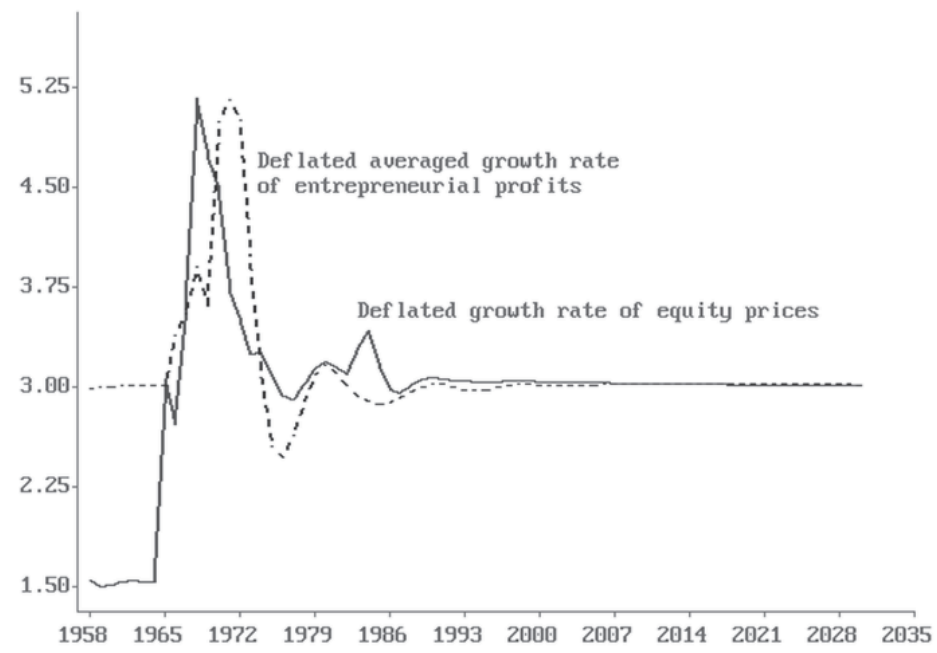


Finally, as mentioned at the beginning of this subsection, the decision to raise the proportion of investment financed by retained earnings implies a decrease in the issue of stock market equities (actually, in the experiment, the change implies that equities are not issued any more). As there are less equities outstanding, this leads to an increase in the price earnings ratio, and to a more obvious increase in Tobin's q ratio, as shown in Figure Id. The next chart, Figure Ie, shows the evolution of the growth rate in equity prices, deflated by the overall price index, as well as that of some weighted average of the growth rate in entrepreneurial profits of firms, deflated in the same manner. As one would expect, deflated profits start by growing at $3 \%$, as all real variables do in the base line steady state, and they end back growing at $3 \%$ in the new steady state. By contrast, it may be noted that equity prices were initially growing at only I.50\%, and that they hiked up to above $5 \%$ when firms took the decision not to issue equities anymore. The (deflated) growth rate of equity prices then gravitates towards a $3 \%$ rate. Why then did equity prices not grow at $3 \%$ in the baseline steady state? It is because, in a steady state, the value of all portfolio assets must grow at the same rate. But the value of equities is made up of a price times the number of equities. The growth rate of the value of equities is thus made up of three components, the growth rate of equity prices, the growth rate in the number of equities, and the product of these two growth rates. In the base line solution, firms did issue new equities, and as a consequence the deflated growth rate of equity prices had to be smaller than $3 \%$.

It is not quite clear how equity issues are related to financialization. Even at the height of the stock market boom, when start-up companies were issuing billions of equities and making rich their creators, the overall amount of equities was often decreasing. Financialization may thus be associated with lower or higher rates of equity issues. In the present case, with relatively more retained earnings, the overall effects on the economy are negative, as output and employment fall relative to the base case. Rentiers, however, will be quite happy, with equity prices being much higher now than they were in the base case. Restricting equity issues is thus beneficial to rentiers, at least in our model with its current parameter values.

\subsection{Increasing the Proportion of Profits Distributed as Dividends}

Among the many facets of financialization that have been noted by a number of researchers is the apparent increase in the proportion of profits that are distributed as dividends to shareholders (Cordonnier 2006). This proportion is a parameter of our model. We assume that firms distribute in period $t$ a fraction $\Psi_{D}$ of the profits that they realized in period $t-1$. What happens if firms decide or accept to raise this fraction? To find out, we can examine the evolution of exactly the same variables that we charted in the previous subsection.

There is a certain degree of similarity with the previous experience. Raising the fraction of profits going to dividends leads once more to an increase in the mark-up, and hence to an increase in the share of profits in national income. The higher mark-up, through conflict inflation also leads to faster wage inflation, and hence to faster price inflation. The evolution of the costing margin and that of inflation are illustrated in Figures $2 \mathrm{a}$ and $2 \mathrm{~b}$, showing some similarities with Figures Ia and $\mathrm{Ib}$. Things, however, are different from now on. 
Figure 2a: Evolution of the Costing Margin of Firms, Following an Increase in the Fraction of Profits Which is Distributed as Dividends

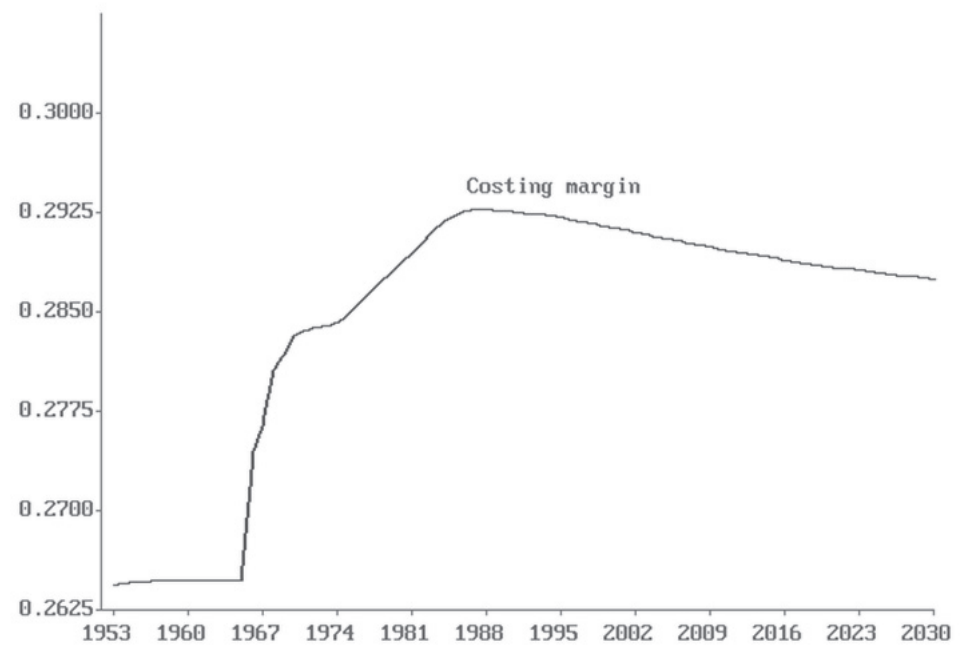

Figure 2b: Evolution of the Wage Inflation, Following an Increase in the Fraction of Profits Which is Distributed as Dividends

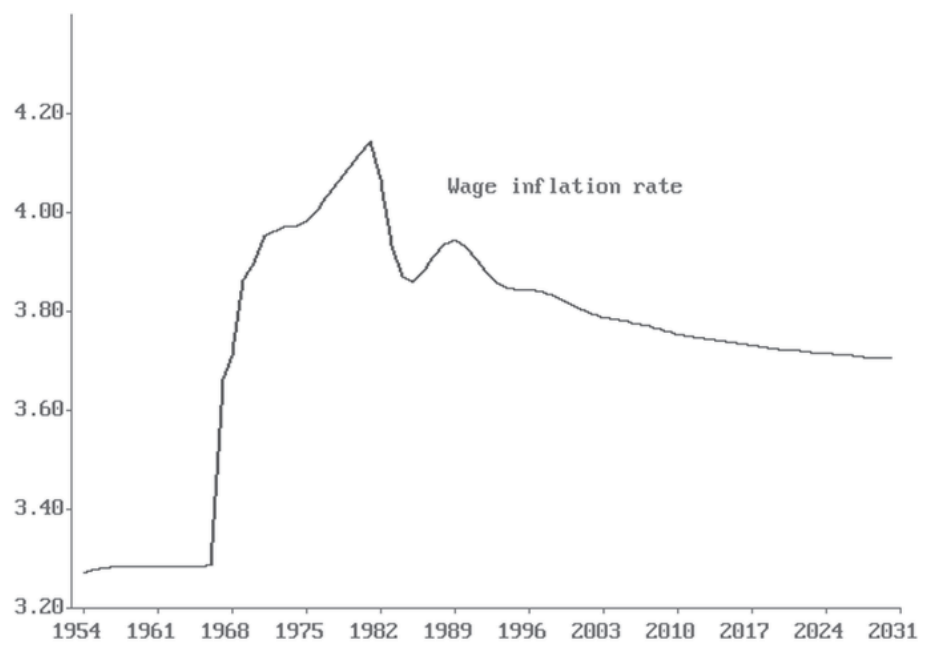


Figure 2c: Evolution of the Employment Rate and of Real Consumption, Relative to the Baseline Solution, Following an Increase in the Fraction of Profits Which is Distributed as Dividends

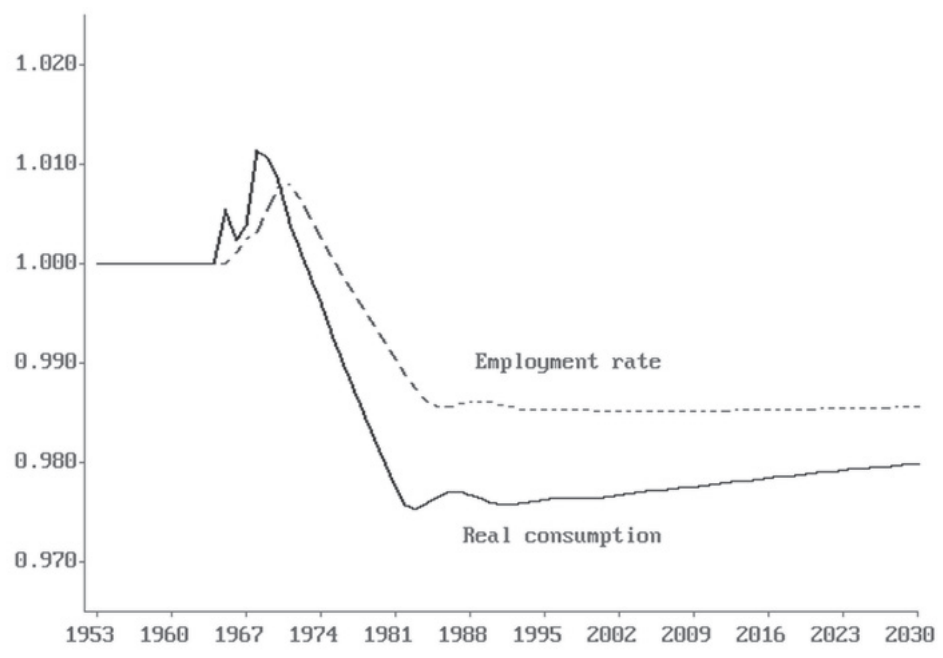

Figure 2d: Evolution of Tobin's q Ratio and the Price Earnings Ratio, Relative to the Baseline Solution, Following an Increase in the Fraction of Profits Which is Distributed as Dividends

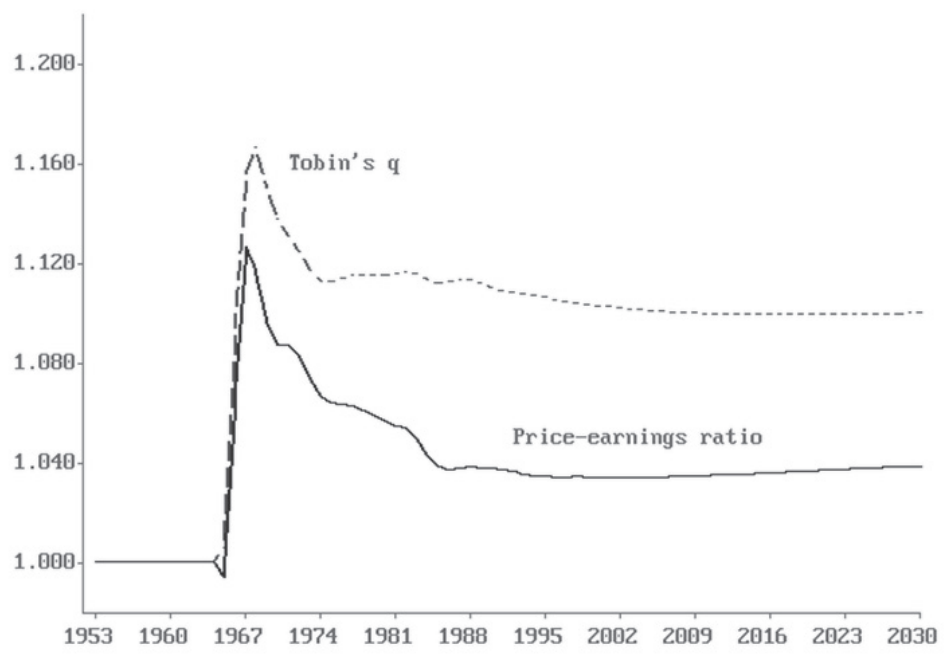


Figure 2e: Evolution of the Lending and Deposit Rates, Following an Increase in the Fraction of Profits Which is Distributed as Dividends

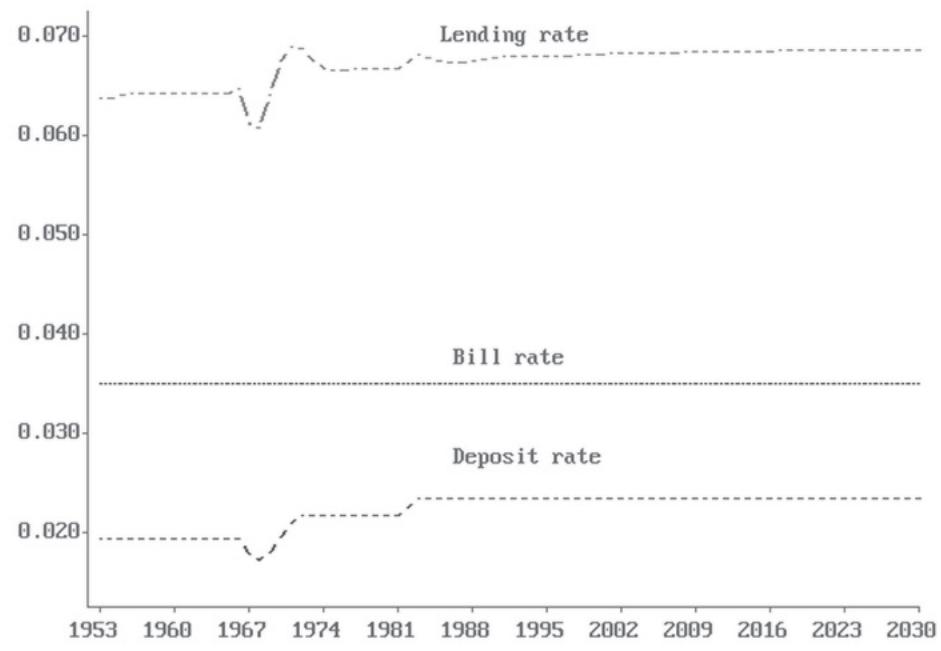

Soon after the increase in the dividend rate, employment, real output and real consumption rise (see Figure $2 \mathrm{c}$ ), as households can now spend more out of their dividends. The increase in economic activity also arises from another source. With more dividends, the stock market booms, with rising price earnings ratios (Figure $2 \mathrm{~d}$ ). Despite this, in the long run employment, real output, and real consumption are all lower than in the baseline case, once again because of the recessionary inflation effects.

In this case, one of the features of financialization, a higher fraction of profits distributed as dividends, has positive short-run effects on the overall economy and the rentiers, but these effects vanish over the long run, even becoming negative when looking at the overall economy.

I have also included an additional chart, that of Figure 2e, which shows the evolution of the rate of interest on bank deposits and the rate of interest on loans, both rates showing a downward blip, only to recover at a level which is higher than the baseline case. Some of the non-linear features of the model are now obvious. The change in the fraction of profits distributed as dividends has consequences on both the liquidity ratio and the capital adequacy ratio of banks, thus leading to unexpected changes in the deposit rate and the lending rate of banks, even though the central bank is assumed to keep constant the yield on Treasury bills. This clearly shows that all parts of the model are interrelated. 


\section{The Impact of Parameter Changes Related to Households}

\section{I An Increase in the Desire to Hold Equities}

We now move on to discuss the impact of changes in parameters related to the behaviour of households. We start with a change in household liquidity preference. We shock our growth model by introducing an increase in the preference for stock market equities, a key feature, or so it seems, of financialization across countries. Because of the adding-up constraints, a higher desire to hold equities in the portfolio equations implies that at least one of the other parameters of the portfolio equations must be reduced. We first assume that households decide to reduce their money deposits to acquire more stock market equities.

The implications of such a change, relative to the baseline solution, are illustrated in Figure 3a. First, the share of equities in the wealth of households which is held in the form of financial market assets (money deposits, bills, bonds and equities) does rise, nearly by definition. The increase in the demand for equities gets reflected in the higher equity prices. Hence as a result, the price earnings ratio jumps, and so does Tobin's q ratio. There is some overshooting in the reaction of all these ratios, but long run steady state values are all greater than in the baseline case, as one would expect.

The reduction in liquidity preference leads to other substantial consequences. As shown in Figure $3 \mathrm{~b}$, real consumption and real output relative to the baseline case increase, since real wealth, which has increased considerably because of large capital gains on stock market equities, is an argument in the consumption function. Surprisingly, the long run level of real output, relative to the base line case, is not any higher - indeed it is somewhat lower. This would seem to be best explained by the fact that gross real investment, relative to the baseline case, is dropping.

Why is the rate of accumulation dropping below the trend rate? The answer must be found within the banking system. A quick look at the banking system reveals that the bank liquidity ratio has taken a hard hit, due to the fact that households have reduced the size of their bank deposit holdings in their attempt to purchase additional stock market equities. Banks can absorb this deposit drain, but the buffer is made up of their bill holdings, which must decline drastically. ${ }^{8}$ To recover a proper bank liquidity ratio, banks must raise the deposit rate, and this is what they do, as can be seen in Figure $3 \mathrm{c}$. But since banks must also preserve their profitability and their own funds, they must also raise the lending rate, thus driving up the real rate of interest that enters into the accumulation function. This is why investment drops relative to the baseline case.

8 In the present experiment, the number of bills held by banks even becomes negative, which implies that banks must borrow them from the central bank, but the mechanism has not been made explicit. 
Figure 3a: Evolution of Tobin's q Ratio, the Price Earnings Ratio and the Share of Equities in Household Wealth Detained in the Form of Financial Market Assets, All Relative to the Baseline Solution, Following an Increase in the Household Desire to Hold Stock Market Equities

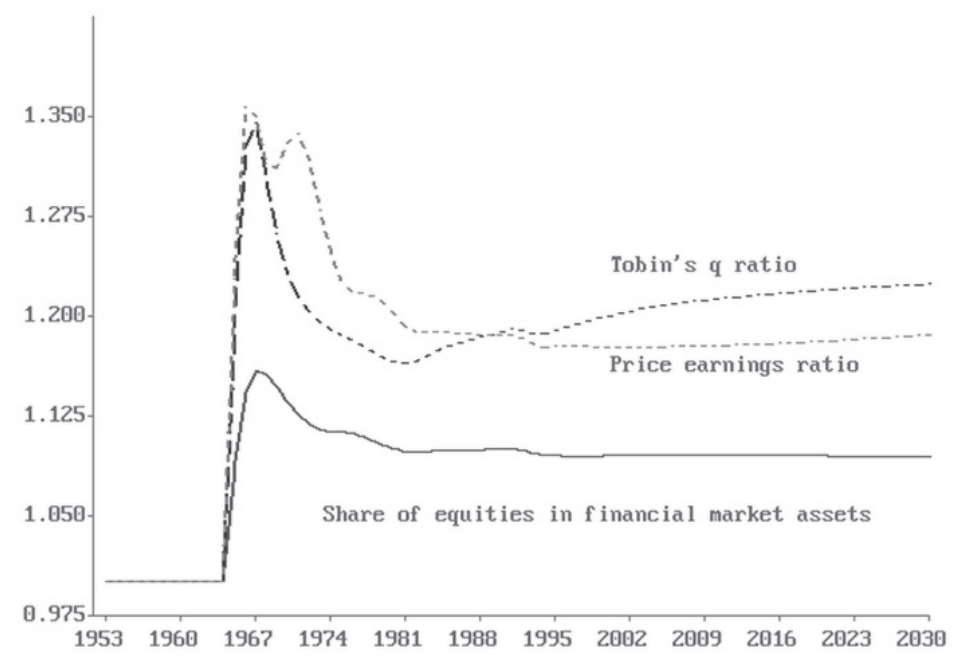

Figure 3b: Evolution of Real Wealth, Real Consumption, Real Output and Real Gross Investment, All Relative to the Baseline Solution, Following an Increase in the Household Desire to Hold Stock Market Equities

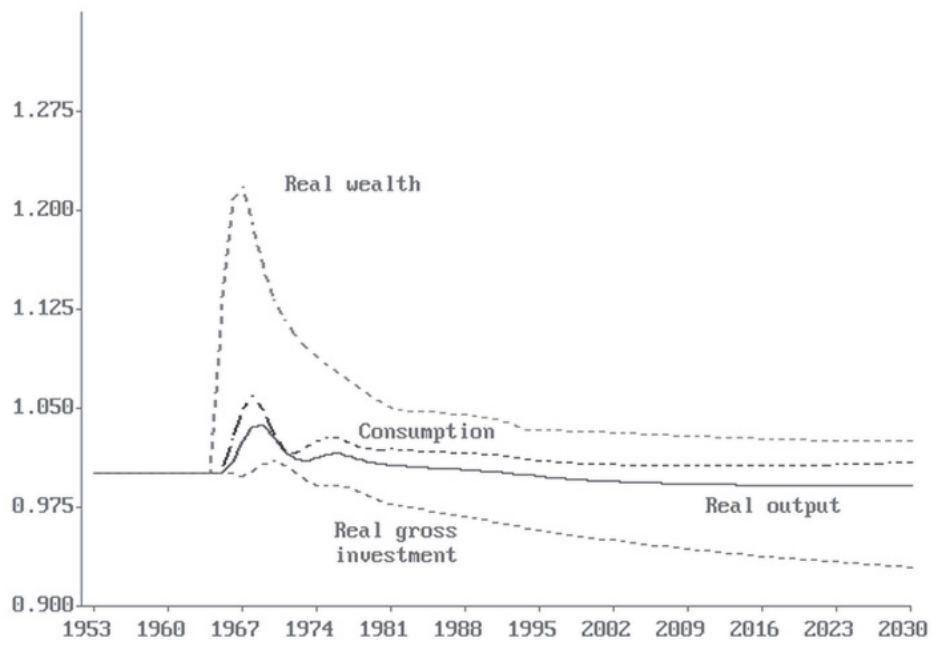


Figure 3c: Evolution of the Lending Rate and the Deposit Rate, Following an Increase in the Household Desire to Hold Stock Market Equities, When This Desire is Compensated by a Drop in the Desire to Hold Bank Deposits

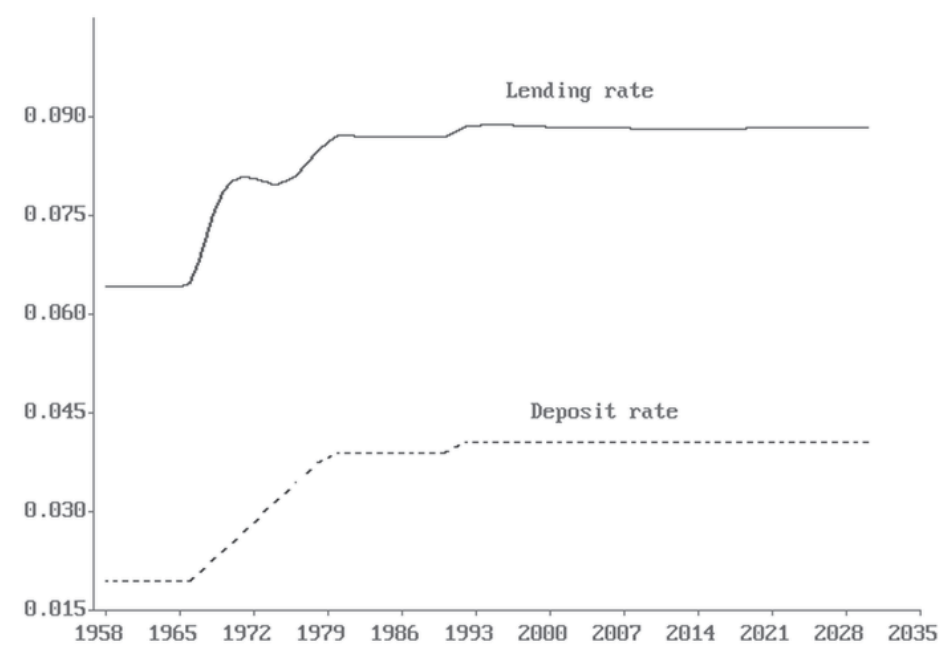

Figure 3d: Evolution of the Lending Rate and the Deposit Rate, Following an Increase in the Household Desire to Hold Stock Market Equities, When This Desire is Compensated by a Drop in the Desire to Hold Bills and Bonds

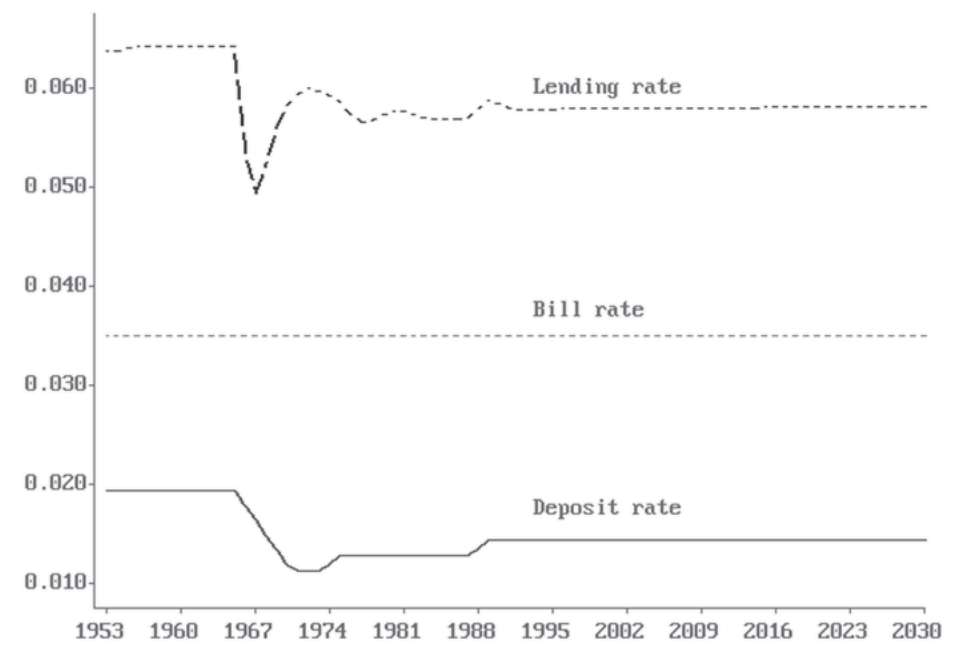


But things would have been completely different had households switched to stock market equities by reducing their holdings of government bonds and bills instead of reducing the size of their bank deposits. Figure $3 \mathrm{~d}$ shows what would have happened in this case. The bank liquidity ratio is driven up, as households sell their bonds and bills, with some of the latter being acquired by banks. As a result, with the liquidity ratio beyond the upper threshold, banks reduce the deposit rate in an attempt to get the liquidity ratio back to its normal range, and the lending rate follows the decrease in deposit rates.

Comparison of Figures $3 \mathrm{C}$ and $3 \mathrm{~d}$ explains why it is important to be explicit about all portfolio equations. The implications on interest rates of an increase in the propensity to hold stock market equities turn out to be quite different, depending on whether the counterpart to this increase is to be found in a decrease in the propensity to hold money deposits, which is the residual equation in the portfolio system, or in a decrease in the propensity to hold bills and bonds. Once again, only a full-fledged model can differentiate between the implications of these different assumptions regarding the portfolio behaviour of households. An explanation of the evolution of lending and deposit rates cannot rely on a simple partial equilibrium model.

\subsection{An Increase in the Ratio of Gross New Loans to Personal Income}

We now proceed to our last experiment, linked to household borrowing. Once again, this seems to be a key feature of financialization, with households being allowed and being encouraged to borrow sums of money which represent a much larger proportion of their personal income. In our model, the major parameter of household behaviour with respect to debt is $\eta$, which represents the gross value of new loans as a proportion of personal income that households are willing to take on, or are allowed to take on, in every period (this, for once, is a flow-flow norm).

Figure 4a shows, as one would expect, that the increase in the willingness to take on new loans leads to an increase in both the personal loans to personal income ratio and the debt-service burden of personal debt. Households thus decide to take on more debt as a proportion of their personal income, and this debt carries a heavier weight - interest payments and principal repayment - relative to their personal income. What are the consequences of this greater household willingness to go into debt (or the greater willingness of banks to grant credit to the household sector)?

Figure $4 \mathrm{~b}$ shows the consequences for real consumption and real output. In the short run, this greater willingness to borrow leads to higher consumption and higher real GDP relative to the base line case. The positive effect, however, is only temporary. It is followed by a reversal, so that in the new steady state real consumption and real output (and hence the employment rate) are lower than they would have been in the baseline scenario. These results thus give support to the arguments advanced by Palley (1996: 213), who wrote that, in the case of household debt, "the crux of the argument is that borrowing initially serves to increase aggregate demand and output, but that debt service payments subsequently serve 
to reduce them«. Consumers must eventually pay more interest on their debt, thus reducing their net disposable income available for consumption.

Figure 4a: Evolution of the Personal Loans to Personal Income Ratio and of the Burden of Personal Debt, Following an Increase in the Gross New Loans to Personal Income Ratio

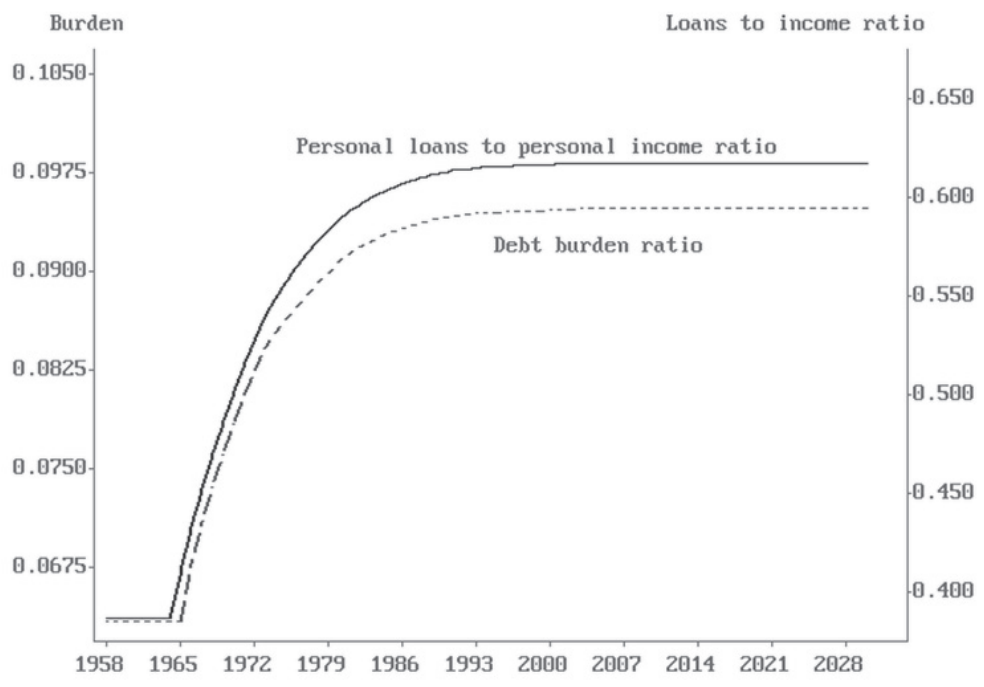

Figure 4b: Evolution of Real Output and Real Consumption, Relative to the Baseline Solution, Following an Increase in the Gross New Loans to Personal Income Ratio

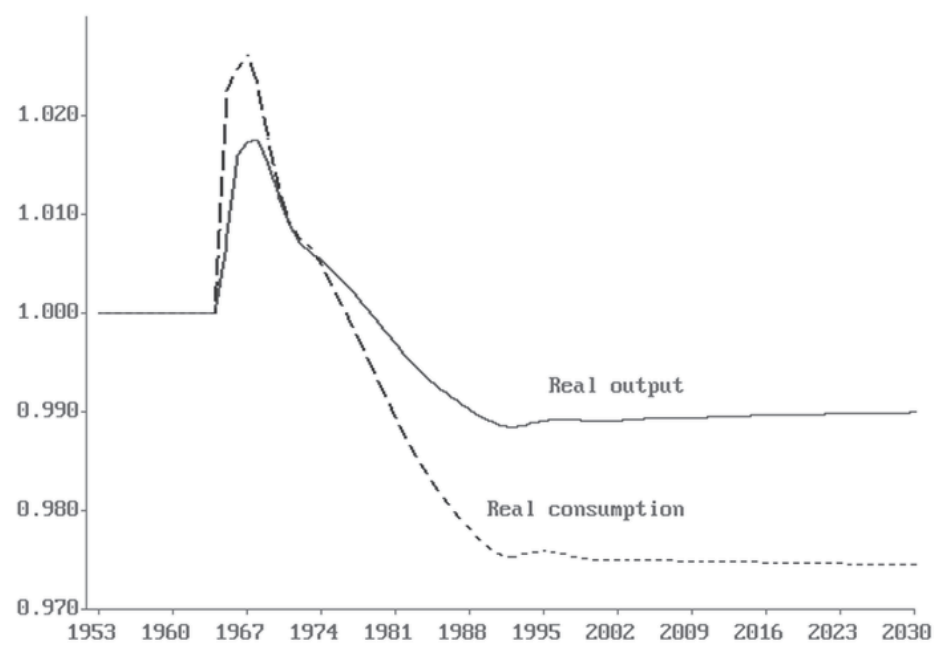


Figure 4c: Evolution of the Bank Capital Adequacy Ratio and of the Bank Liquidity Ratio, Relative to the Baseline Solution, Following an Increase in the Gross New Loans to Personal Income Ratio

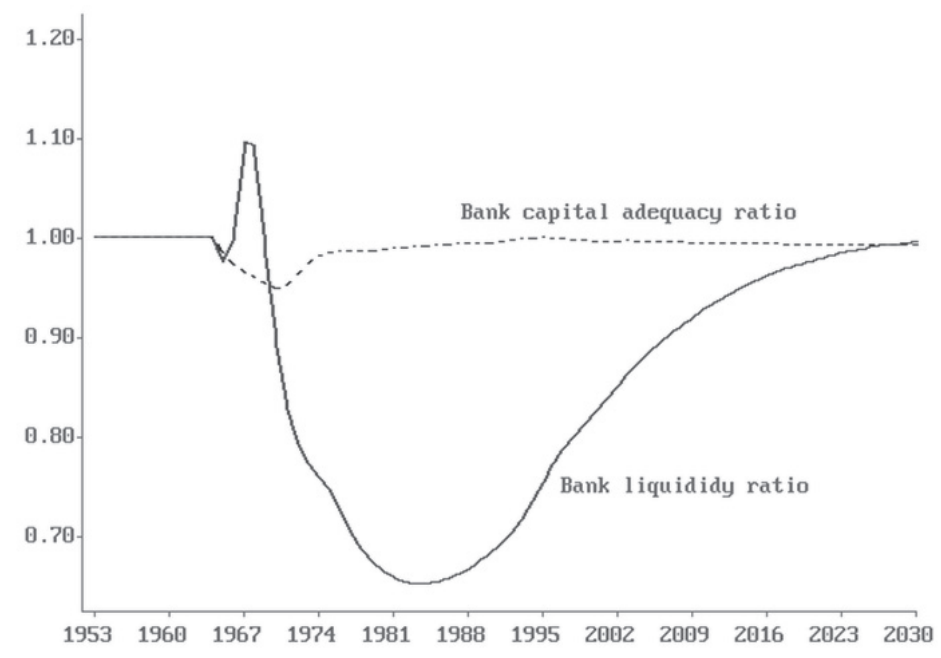

Figure 4d: Evolution of the Lending Rate Set by Banks, Following an Increase in the Gross New Loans to Personal Income Ratio

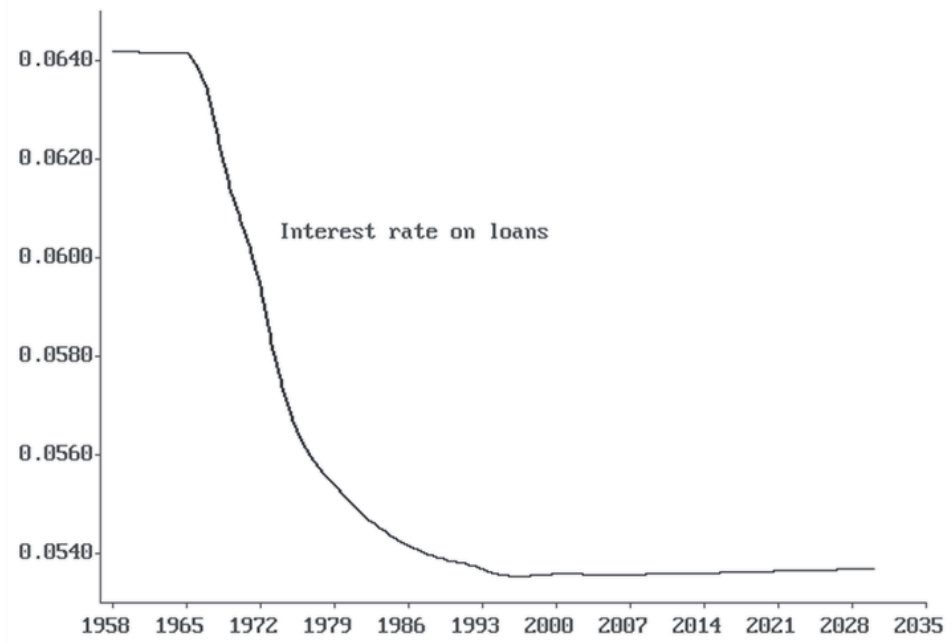


Fig 4e: Evolution of the Government Deficit to GDP Ratio and of the Government Debt to GDP Ratio, Relative to the Baseline Solution, Following an Increase in the Gross New Loans to Personal Income Ratio

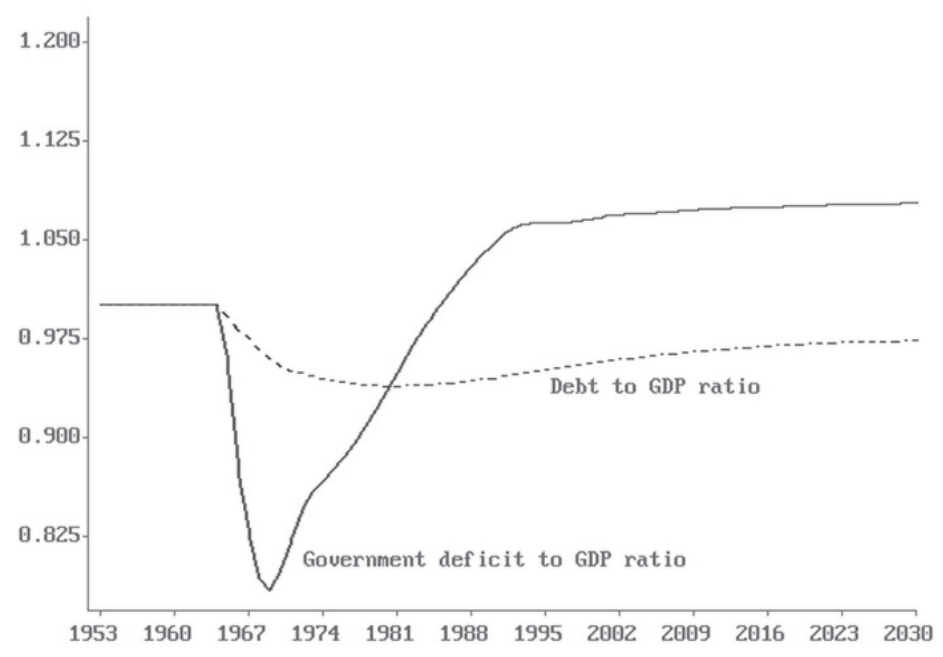

The picture shown in Figure $4 \mathrm{~b}$ has interesting implications for the evolution of many OECD countries, most notably the USA and Canada, where aggregate demand over the last ten years or so has been sustained by a continuous expansion in the personal debt of households relative to their personal income (Godley 1999, Godley/Zezza 2006, Seccareccia 2005). Several authors have wondered whether such growth regimes, where the expansion of the economy is essentially driven by the willingness of households to accept ever higher debt to income ratios, could go on much longer. Figure $4 \mathrm{~b}$ illustrates the fact that, even if households do nothing to reduce their debt to personal income ratio or their debt-servicing ratio, letting them rise towards their steady state levels, there is some likelihood that aggregate demand in the future will be negatively affected by the past decisions to increase the flow of new loans relative to personal income.

We also explore the implications of higher personal debt ratios for other sectors of the economy. Figure $4 \mathrm{C}$ shows what happens to the main ratios of the banking sector. Despite the increase in loans to the private sector, banks have no trouble keeping their capital adequacy ratios at the proper level (indeed the lending rate does not even need to be raised; it falls as shown in Figure 4d). On the other hand, there are some large fluctuations in the bank liquidity ratio, but this ratio returns to its initial position endogenously, without any change in the deposit interest rate. Thus the banking sector is able to absorb quite large fluctuations in loans to the personal sector.

The consequences for the finances of the public sector are shown in Figure 4e. In the short run, when the economy speeds up thanks to the borrowing binge of the household 
sector, the government deficit to GDP ratio drops, and so does the government debt to GDP ratio. However, as the negative effects of increased household borrowing take their toll on the economy, the government deficit to GDP ratio moves back up, at an even higher level than in the baseline case. We thus observe that the evolution of the financial ratios of the government sector depends heavily on the saving or borrowing decisions of households - a point that we hammer in our book and more specifically in a recent paper (Godley and Lavoie 2007b).

\section{Additional Issues Related to the Recent Financial Crisis}

Before concluding, a few remarks about the financial crisis that rocked the world economy in August 2007 and after are in order. Strictly speaking, this crisis cannot be represented in our model since it involves some financial institutions being refused intraday credit within the clearing and settlement payment system. We would need to describe at least two sets of banking institutions, whereas we have only one. However, we can presume that the financial crisis makes banks more prudent in their lending behaviour. This implies that the debt parameter $\eta$, the gross value of new loans as a proportion of personal income that households are willing, or rather, in this case, are allowed to take on, would suddenly drop down. The results that we obtained in the last section would thus be reversed: in the short run, there would be a negative effect on income and consumption; in the long run, but how long this will be is hard to say, it would have favourable effects, ceteris paribus.

The same thing would happen if, following the financial crisis, households were being asked to reimburse a greater proportion of their loans each period (the loan repayment ratio is larger). In the short run the household burden on personal debt gets heavier, but this burden eventually decreases, as can be seen in Figure 5a. The reduction occurs because we have assumed that households set as a target the amount of gross new loans relative to personal income. Since the amount of new loans is left unchanged relative to the baseline case, net new loans diminish because of the more substantial reimbursements, thus inducing a reduction in the household ratio of personal loans to personal income. The larger repayment ratio initially slows down the economy, as one would expect, but eventually, as can be seen from Figure $5 \mathrm{~b}$, consumption overtakes baseline consumption.

There is another parameter in our model that could take into account some of the effects of the crisis: there is a parameter that measures the proportion of bank loans made to firms that default (unfortunately, we had no similar parameter for bank loans made to households). The increase in the percentage of non-performing loans brings about a sharp decline in the capital adequacy ratio of banks (Figure 6a). Banks however manage to bring back the actual capital adequacy ratio towards its normal level within a short time period. How is this accomplished? Figure $6 \mathrm{~b}$ shows us how. The spread between the lending rate and the deposit rate is pushed up; in other words, banks raise their profit margins. Because the actual bank liquidity ratio rises (banks have less loans on their balance sheet!), the deposit rate moves down, thus allowing the banks to keep the lending rate at a level which is 
Figure sa: Evolution of the Personal Loans to Personal Income Ratio and of the Burden of Personal Debt, Following an Increase in the Loan Repayment Ratio

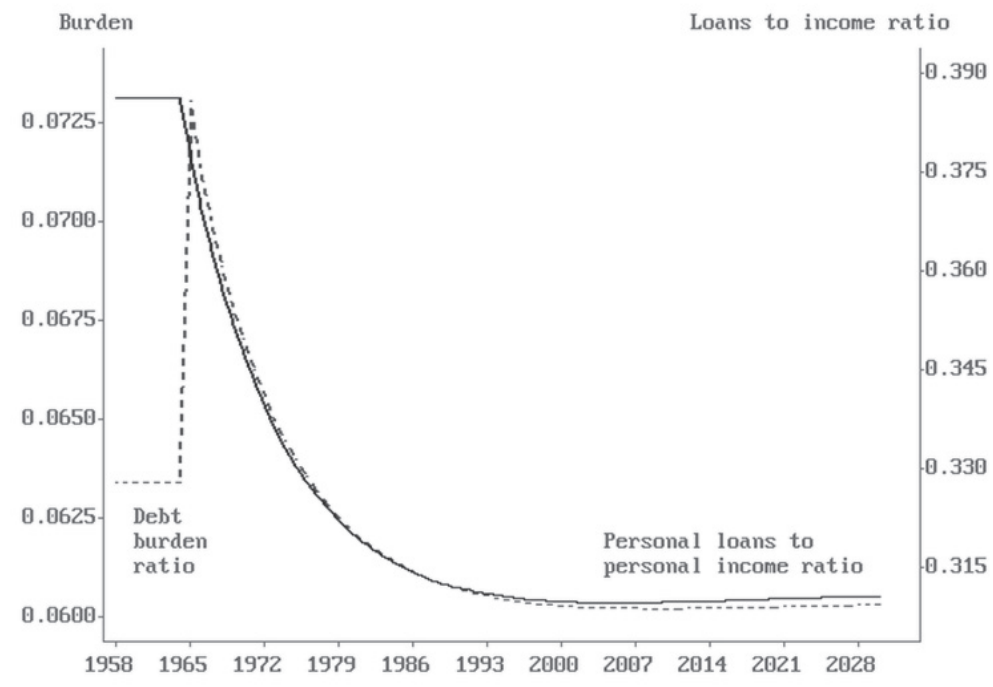

Figure 5b: Evolution of Real Output and Real Consumption, Relative to the Baseline Solution, Following an Increase in the Loan Repayment Ratio

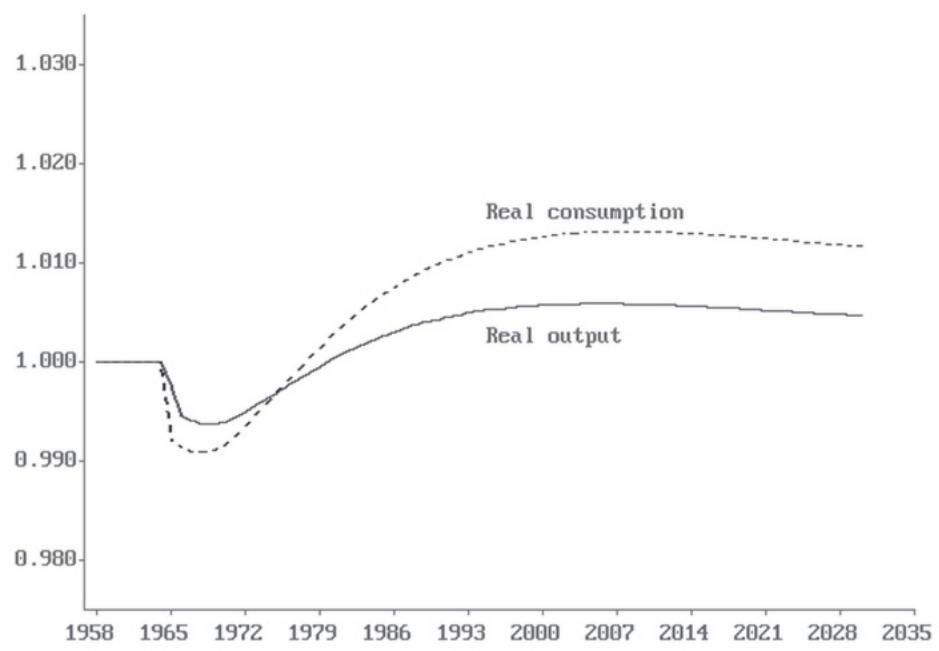

not exceedingly higher than the base line solution lending rate. As one would expect, the short-run effects of an increase in defaulting loans is a reduction in output and consumption relative to the baseline solution. 
Figure 6a: Evolution of the Actual Bank Capital Adequacy Ratio, Following an Increase the Percentage of Non Performing Loans (Defaulting Loans)

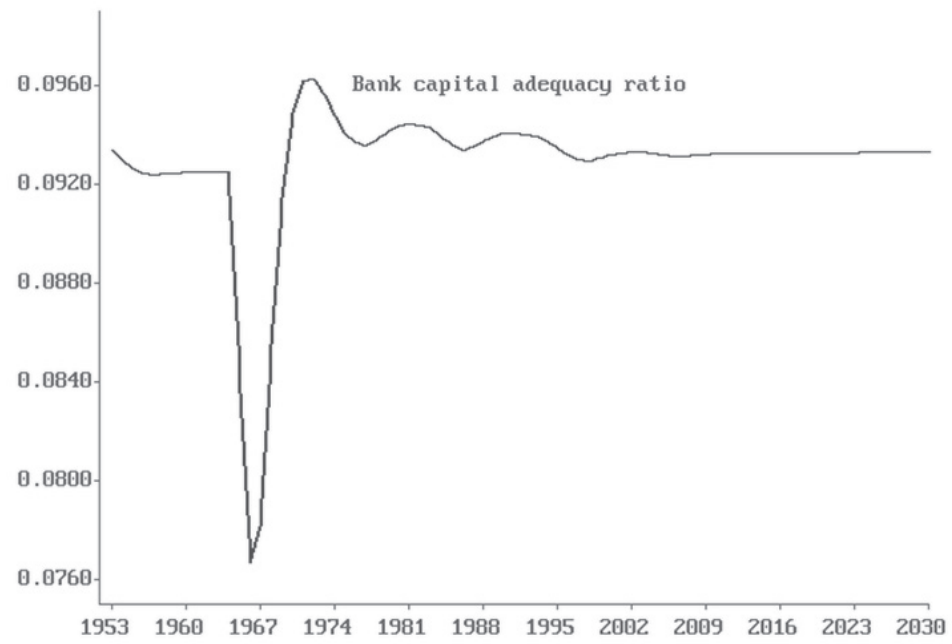

Figure 6b: Evolution of the Lending Rate and Deposit Rate, Relative to the Baseline Solution, Following an Increase the Percentage of Non Performing Loans (Defaulting Loans)

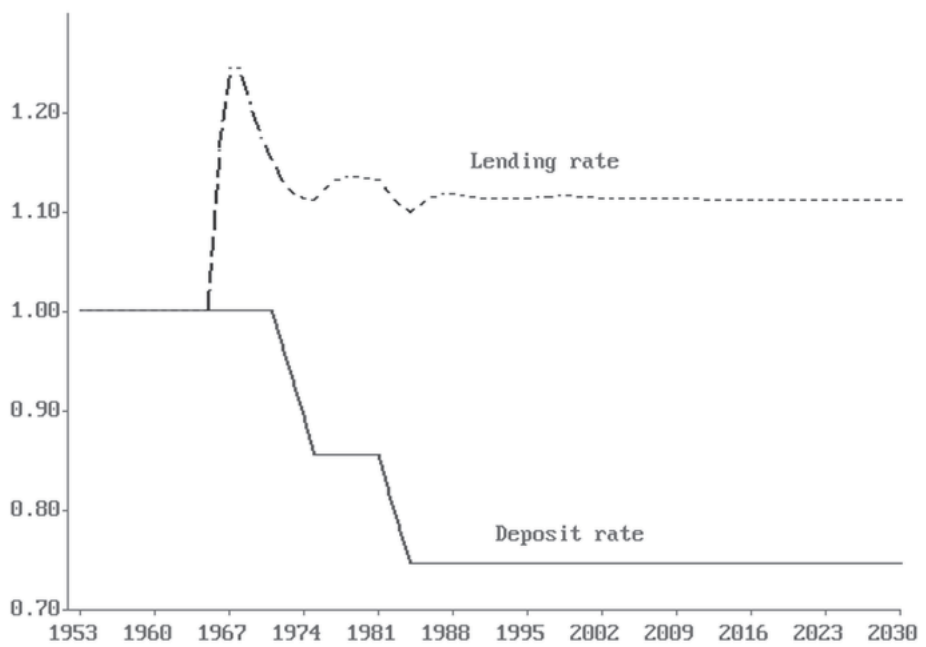




\section{Conclusion}

In the Godley and Lavoie (2007a) book we emphasized the importance of dealing with stock-flow consistent models. In its introduction, we pointed out that stock-flow monetary analysis has been a long-standing feature of Post-Keynesian economics, as it can be found, without giving references, in the works of Minsky, Davidson, Chick, Eichner, and Skott. Flow-of-funds analysis, which we believe is closely tied to this stock-flow monetary analysis, has been mainly created and endorsed by other heterodox authors - for example Institutionalists. There is thus some obvious affinity between heterodox work and stock-flow consistent modeling. We do not say that everyone should be busily constructing stock-flow consistent models. As pointed out above, this method has some advantages but also some drawbacks, as its requirements quickly become burdensome.

In this paper we have examined the possible effects of changes in six parameters linked with increased financialization. While some effects are to be expected, others are not, especially the impact on lending and deposit rates. Thus how exactly the banking sector reacts or is presumed to react to changes in its balance sheet makes a great deal of difference. In addition, one must be very careful to distinguish between the short-run and the long-run effects, as short-run conditions themselves generate further additional effects that sometimes tend to dampen or even overturn the initial impact of a change in parameters.

\section{References}

Brennan, D.M. (2008): Co-opting the shareholder value movement: A class analytic model of share repurchases, Review of Radical Political Economics, 40(I), 89-106.

Clévenot, M. (2006): Financiarisation, régime d'accumulation et mode de régulation: Peut-on appliquer le modèle américain à l'economie française?, $\mathrm{PhD}$ dissertation, University of Paris-Nord, Paris-I3, URL: http://tel.archives-ouvertes.fr/tel-ooi20886/en/.

Cordonnier, L. (2006): Le profit sans l'accumulation: La recette du capitalisme gouverné par la finance, Innovation: Cahiers d'économie de l'innovation, 23(I), 5I-72.

Cripps, F., Godley, W. (1976): A formal analysis of the Cambridge Economic Policy Group model, Economica, 43, 335-348.

Dos Santos, C.H. (2006): Keynesian theorising during hard times: Stock-flow consistent models as an unexplored frontier of Keynesian macroeconomics, Cambridge Journal of Economics, 30(4), 54I-565.

Duménil, G., Lévy, D. (1993): The economics of the profit rate: Competition, crises and historical tendencies in capitalism, Aldershot: Edward Elgar.

Duménil, G., Lévy, D. (200I): Crise et sortie de crise: Ordres et désordres néolibéraux, Paris: Presses Universitaires de France.

Epstein, G.A. (ed.) (2005): Financialization and the world economy, Cheltenham: Edward Elgar. 
Godley, W. (1999): Seven unsustainable processes: Medium-term prospects and policies for the United States and the world, Strategic Analysis, The Levy Economics Institute of Bard College.

Godley, W., Cripps, F. (1983): Macroeconomics, London: Fontana.

Godley, W., Lavoie, M. (2007a): Monetary economics: An integrated approach to credit, money, income, production and wealth, London: Palgrave Macmillan.

Godley, W., Lavoie, M. (2007b): Fiscal policy in a Stock-Flow Consistent (SFC) model, Journal of Post Keynesian Economics, 30(I), 79-100.

Godley, W., Zezza, G. (2006): Debt and lending: A cri de coeur, The Levy Economics Institute of Bard College, Policy Note, No. 2006/4.

Hubbard, R.G., Kuttner, K.N., Palia, D.N. (2002): Are there bank effects in borrowers' costs of funds? Evidence from a matched sample of borrowers and banks, Journal of Business, 75(4), 559-58I.

Kriesler, P., Lavoie, M. (2007): The new consensus on monetary policy and its Post-Keynesian critique, Review of Political Economy, I9(3), 387-404.

Lavoie, M., Godley, W. (200I-2): Kaleckian models of growth in a coherent stock and flow monetary framework: A Kaldorian view, Journal of Post Keynesian Economics, 24(2), 277-3I2.

Layard, R., Nickell, S., Jackman, R. (199I): Unemployment: Macroeconomic performance and the labour market, Oxford: Oxford University Press.

Le Héron, E., Mouakil, T. (2008): A Post Keynesian stock-flow consistent model for the dynamic analysis of monetary policy shock on banking behaviour, Metroeconomica, 59(4), 405-440.

Palley, T.E. (1996): Post Keynesian economics: Debt, distribution and the macro economy, New York: St Martin's Press.

Pasinetti, L.L. (2005): The Cambridge School of Keynesian Economics, Cambridge Journal of Economics, 29(6), 837-848.

Rowthorn, R.E. (1977): Conflict, inflation and money, Cambridge Journal of Economics, I(3), 215-239.

Seccareccia, M. (2005): Growing household indebtedness and the plummeting saving rate in Canada: An explanatory note, Economic and Labour Relations Review, I6(I), I33-I5I.

Skott, P., Ryoo, S. (2008): Macroeconomic implications of financialisation, advance access, published on April $15^{\text {th }}$.

Stockhammer, E. (2004): The rise of unemployment in Europe: A Keynesian approach, Cheltenham: Edward Elgar.

Van Treek, T. (2007): A synthetic stock-flow consistent macroeconomic model of financialisation, Macroeconomic Policy Institute (IMK), Working paper, No. 6/2007.

Zezza, G., Dos Santos, C.H. (2004): The role of monetary policy in Post-Keynesian stock-flow consistent macroeconomic growth models, in: Lavoie, M., Seccareccia, M. (eds.), Central banking in the modern world: Alternative perspectives, Cheltenham: Edward Elgar, I8I-208. 